\title{
Hubungan Karakteristik Topografi dengan Sifat-Sifat Fisika Tanah Studi Kasus: Sub DAS Citarik, DAS Citarum Hulu
}

\author{
Ade Setiawan ${ }^{1)}$, Mahfud Arifin ${ }^{1)}$, Rachmat Harryanto ${ }^{1)}$, dan Apong Sandrawati1)
}

1)Staf Pengajar Fakultas Pertanian Universitas Padjadjaran

Jl. Raya Bandung Sumedang Km 21 Jatinangor

Korespondensi: de_setiawan@yahoo.com

\begin{abstract}
The proper understanding about spatial soil diversity is very important to simulate environmental model and to manage land resources in the landscape scale. Information of soil diversity is also noteworthy for environmental academics, forestry, civil engineering, and land use planner. Until now, most of the soil information are derived from conventional soil maps which are lack of detailed information. This condition can increase the uncertainty of model output and can also be an obstacle to the future development of spatial distribution model. According to this situation, the research was conducted in Sub Watershed of Cikeruh, Citarik, and Citarum Hulu. These

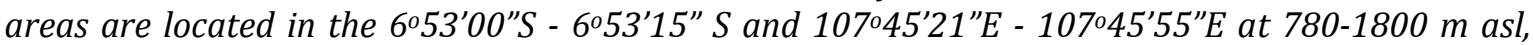
The rainfall is classified as type $C$ according to the Schmidt and Fergusson classification with mean rainfall around $1795.66 \mathrm{~mm}$ per year. The soils in the research areas are classified as Inceptisols. The research aims to analyze and elucidate the relation between topographic characteristics and soil physical properties. Some parameters studied in this research are elevation, aspect, plan curvature, profile curvature, topographic wetness index (TWI), topographic position index (TPI), and some soil physical properties, such as soil texture (clay, silt, and sand), soil organic carbon, soil bulk density, soil available water capacity, soil porosity and permeability. The results showed that all topographic parameters were related to one or some soil physical properties, except aspect and slope. Topographic variables that are frequently related to soil properties are TPI and TWI.
\end{abstract}

Keywords: topographic characteristics, elevation, aspect, curvature, TWI, TPI, soil physical properties

\section{PENDAHULUAN}

Tanah sebagai suatu sistem yang kompleks dan bersifat dinamis, selalu mengalami perubahan secara terus menerus. Perubahan ini merupakan hasil dari proses penambahan, kehilangan, pemindahan dan transformasi energi dan materi. Proses-proses tersebut bersifat khas sehingga menghasilkan keragaman tanah dengan morfologi yang khas dan berbeda secara spasial dan temporal dalam sifat fisik, kimia, biologi, morfologi dan mineralogi (Simonson, 1968; Wilding dan Drees, 1983). Pola keragaman yang terbentuk tergantung dari interaksi antara faktor-faktor pembentuk tanah yang menurut Jenny (1941) terdiri dari bahan induk, topografi, iklim, organisme dan waktu.

Pada kondisi iklim, geologi dan penggunaan lahan yang homogen, topografi merupakan faktor penting yang berperan dalam proses pembentukan tanah. Salah satu komponen dari topografi adalah posisi landskap. Sifat-sifat tanah sudah sejak lama diketahui berhubungan dengan posisi landskap (Ruhe, 1956). Terdapat dua pendekatan dasar dalam mencari pola hubungan antara tanah dengan posisi landskap (Pachepsky et.al, 2001). Pertama, didasarkan pada pemisahan hillslopes ke dalam beberapa satuan lereng, yaitu puncak (summit), interfluve, bahu lereng (shoulder), punggung lereng (backslope), lereng lurus, kaki lereng (footslope), dasar lereng (toeslope). Kedua, dengan menggunakan karakteristik topografis atau terrain attribute. Terrain attribute merupakan karakteristik matematis dari bentuk permukaan lahan, seperti slope; altitude; curvature (profil, plan dan tangential); flow path length dan aspect 
(Evans, 1980; Moore et al., 1991; Mitasova dan Hofierka, 1993; Shary, 1995).

Karakteristik topografis pada suatu landskap bisa diturunkan secara langsung dari data Model Elevasi Digital (DEM). Variabel topografis dapat digunakan untuk membagi terrain ke dalam area yang secara jelas mempunyai bentuk. Variabel topografis juga dapat digunakan untuk membuat terrain attributes sekunder, seperti topographic wetness index, atau index pengangkutan sedimen (sediment transport index) yang dapat digunakan dalam analisis korelasi antara sifat-sifat tanah dengan landskap (McKenzie dan Ryan, 1999). Asumsi dasar di belakang model-model ini adalah adanya keterkaitan antara sifat-sifat tanah dan karakteristik landform. Pendekatan ini sangat membantu dalam pemetaan tanah diantaranya yaitu untuk menjelaskan hubungan antara sifat-sifat tanah dengan landskap (Zhu et al., 2001).

\section{METODOLOGI}

Penelitian dilaksanakan di daerah Sub-sub DAS Cikeruh, Sub DAS Citarik, DAS Citarum

Tabel . Karakteristik topografi seperti elevasi, kemiringan, curvature dihitung langsung dari data DEM dengan menggunakan
Hulu. Daerah ini terletak pada ketinggian 780$1.800 \mathrm{~m}$ di atas permukaan laut, $6^{\circ} 53^{\prime} 00^{\prime \prime} \mathrm{sd}$.

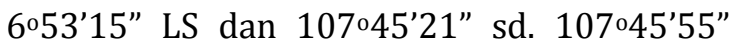
BT.

Metode penelitian kuantitatif yang digunakan adalah metode penelitian noneksperimental (observasi), yaitu melalui metode survei, deskriptif dan korelasional. Metode survei yang digunakan adalah metode bebas atau metode satuan lahan. Pengambilan contoh tanah dilakukan dengan metode stratified purposive sampling. Variabel-variabel yang diteliti yaitu elevasi, aspect, plan curvature, profil curvature, Topographic Wetness Index (TWI), Topographic Position Index (TPI) dan beberapa sifat fisika tanah.

Analisis Morfometri dilakukan untuk memperoleh karakteristik topografi primer dan sekunder. Karakteristik topografi dalam penelitian ini diperoleh dari model elevasi digital dengan jarak grid $5 \mathrm{~m}$ yang dibuat dari hasil survei topografis secara detail dengan menggunakan metode interpolasi kriging. Ringkasan metode perhitungan disajikan pada

fungsi standar ArcGIS. Topographic Wetnees Index dihitung dengan menggunakan Software DNRß CLASS Spatial.

Tabel 1 Ringkasan atribut topografis yang digunakan dalam analisis

\begin{tabular}{|c|c|c|}
\hline Index & Persamaan*) & Referensi \\
\hline Elevasi & - & \\
\hline Aspek & & \\
\hline Kemiringan (Slope) & $\tan \beta=\sqrt{f_{x}^{2}+f_{y}^{2}}$ & Mitasova dan Hofierka (1993) \\
\hline Profil curvature & $k_{p}=\frac{f_{x x} f_{y}^{2}+2 f_{x y} f_{x} f_{y}+f_{y y} f_{x}^{2}}{p \sqrt{q^{3}}}$ & Mitasova dan Hofierka (1993) \\
\hline $\begin{array}{l}\text { Tangensial/Plan } \\
\text { curvature }\end{array}$ & $k_{t}=\frac{f_{x x} f_{y}^{2}-2 f_{x y} f_{x} f_{y}+f_{y y} f_{x}^{2}}{p \sqrt{q}}$ & Mitasova dan Hofierka (1993) \\
\hline Mean curvature & $k_{m}=\frac{k_{p}+k_{t}}{2}$ & Mitasova dan Hofierka (1993) \\
\hline Wetness Index & $\ln (a / \tan \beta)$ & Beven dan Kirkby (1979) \\
\hline
\end{tabular}

${ }^{*}$ Elevasi, $\mathrm{z}$, diperoleh dari fungsi spline, $\mathrm{z}=\mathrm{f}(\mathrm{x}, \mathrm{y})$ 


$$
f_{x}=\frac{\partial f}{\partial f_{x}} ; f_{y}=\frac{\partial f}{\partial f_{y}} ; f_{x x}=\frac{\partial^{2} f}{\partial x^{2}} ; f_{y y}=\frac{\partial^{2} f}{\partial y^{2}} ; p=\sqrt{f_{x}^{2}+f_{y}^{2}} ; q=p+1
$$

\section{HASIL DAN PEMBAHASAN}

Hasil analisis regresi dan korelasi menunjukkan bahwa tidak semua karakteristik topografi berpengaruh terhadap sifat-sifat fisika tanah (Tabel 2). Beberapa variable menunjukkan hubungan linier dengan sifat-sifat fisika tanah. Semua variabel topografi berhubungan dengan satu atau lebih sifat-sifat tanah, kecuali aspect dan slope yang tidak menunjukkan adanya hubungan dengan parameter sifat-sifat fisika tanah.
Variabel yang paling sering berhubungan dengan sifat-sifat tanah berturut-turut adalah TPI, TWI, elevasi, curvature, plan curvature dan profil curvature. Atribut topografi tersebut sangat besar peranannya dalam mempengaruhi proses pergerakan air permukaan (run off) dan bawah permukaan (infiltrasi dan permeabilitas) yang menjadi agen terjadinya erosi. Hal ini diduga akan mempengaruhi proses-proses perkembangan tanah.

Tabel 2 Matrik Korelasi antara Variabel Topografi dan Sifat-sifat Fisika Tanah

\begin{tabular}{lccccccc}
\hline \multirow{2}{*}{ Sifat Fisika Tanah } & \multirow{2}{*}{ Elevasi } & \multirow{2}{*}{ Aspect } & \multicolumn{2}{c}{ Curvature } & Slope & \multirow{2}{*}{ TPI } & \multirow{2}{*}{ TWI } \\
\cline { 5 - 6 } & & & Plan & Profil & (derajat) & & \\
\hline Liat (\%) & $-0,21$ & $-0,17$ & 0,03 & $\mathbf{- 0 , 4 8} *$ & $-0,24$ & 0,14 & 0,06 \\
Debu (\%) & $\mathbf{0 , 4 2} *$ & $-0,13$ & $\mathbf{0 , 3 6} *$ & $-0,09$ & 0,18 & 0,25 & $\mathbf{- 0 , 3 6} *$ \\
Pasir (\%) & $-0,13$ & 0,30 & $-\mathbf{0 , 3 5} *$ & $\mathbf{0 , 6 0} *$ & 0,11 & $\mathbf{- 0 , 3 7} *$ & 0,25 \\
C-organik (\%) & $-0,27$ & $-0,12$ & $-0,06$ & 0,19 & 0,13 & $\mathbf{- 0 , 4 4} *$ & $\mathbf{0 , 4 5} *$ \\
Bobot Isi (g/cm ${ }^{3}$ ) & 0,33 & 0,09 & 0,08 & $-0,07$ & 0,20 & $\mathbf{0 , 4 1} *$ & $\mathbf{- 0 , 3 9} *$ \\
Kand. Air pF 2.54 (\%v) & $-0,08$ & $-0,17$ & $-0,08$ & $-0,28$ & $-0,19$ & 0,12 & 0,02 \\
Kand. Air pF 4.2 (\%v) & 0,06 & $-0,11$ & $-0,02$ & $-0,22$ & $-0,18$ & 0,26 & $-0,01$ \\
Air Tersedia (\%) & $-0,25$ & $-0,16$ & $-0,11$ & $-0,2$ & $-0,09$ & $-0,15$ & 0,05 \\
Porositas (\%) & $-0,33$ & $-0,09$ & $-0,08$ & 0,07 & $-0,20$ & $\mathbf{- 0 , 4 1} *$ & $\mathbf{0 , 3 9} *$ \\
Permeabilitas & 0,02 & 0,30 & 0,05 & 0,31 & 0,18 & $-0,20$ & $-0,07$ \\
(cm/jam) & & & & & & & \\
\hline
\end{tabular}

\subsection{Elevasi}

Elevasi (ketinggian tempat) hanya berhubungan dengan kandungan debu. Hubungan positif antara debu dengan ketinggian menunjukkan bawah kandungan debu relatif lebih tinggi di daerah sekitar puncak dan sebaliknya, kandungan debu berkurang dengan semakin rendahnya ketinggian suatu tempat dalam profil lereng tersebut. Hal ini diduga debu banyak yang terhanyutkan terbawa aliran air ke bagian hilir sehingga tidak banyak debu yang diendapkan di lereng bagian bawah.

\subsection{Aspect dan Slope}

Semua sifat-sifat fisik tanah yang diamati tidak menunjukkan adanya hubungan bermakna dengan aspect dan slope. Di daerah tropis, aspect tidak terlalu banyak memberikan keragaman proses pedogenesis. Keragaman hanya terjadi pada aspect lereng yang menghadap ke arah timur dan barat. Sebagian besar aspect di lokasi penelitian menghadap ke arah timur. Demikian juga dengan slope, kelas kemiringan lereng di lokasi penelitian sebagian besar sangat curam (rata-rata 48\%) sehingga baik aspek maupun 
slope tidak terlalu banyak mempengaruhi keragaman sifat-sifat fisika tanah.

\subsection{Profil Curvature}

Profil curvature merupakan laju perubahan kemiringan searah dengan lereng sehingga akan mempengaruhi proses hidrologi dan laju pergerakan aliran air. Nilai negatif menunjukkan konfigurasi lereng yang cembung dan nilai positif menunjukkan tingkat kecekungan profil lereng.

Berdasarkan profile curvature (Gambar 1), lahan di lokasi penelitian sebagian besar menunjukkan nilai -5 sampai 5 , hal ini menunjukkan bentuk lereng yang relatif datar. Di beberapa tempat ditemukan bentuk cembung dan cekung sebagai variasi mikrotopografi.

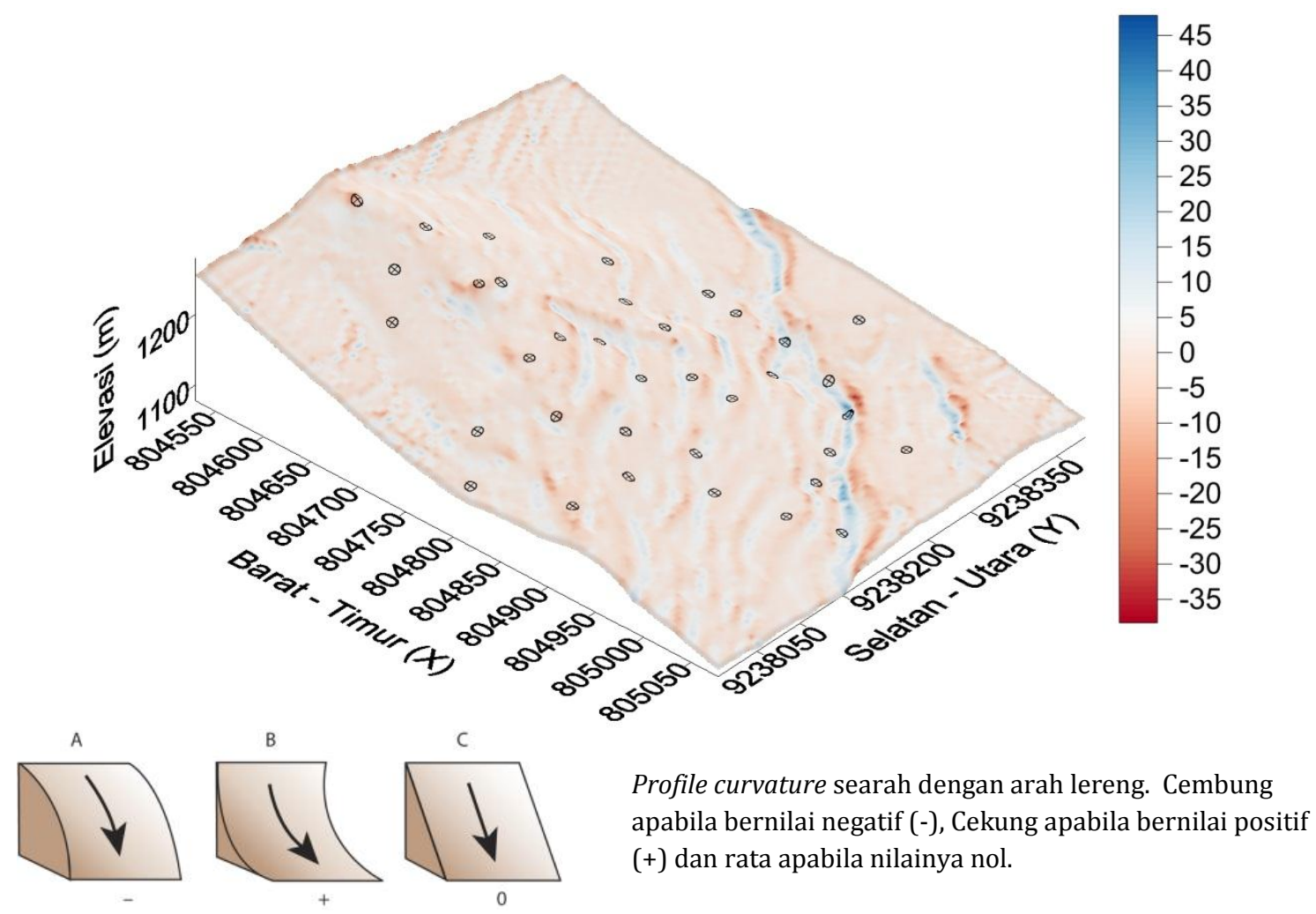

Gambar 1 Hasil interpretasi profile curvature di tempat penelitian

Terdapat hubungan bermakna antara profil curvature dengan kandungan liat dan pasir (Gambar 2). Peningkatan kandungan pasir selaras dengan semakin meningkatnya nilai profile curvature $\left(\mathrm{r}=0,60^{*}\right)$. Hal ini menunjukkan bahwa tinggi rendahnya kandungan pasir tergantung juga pada cekung dan cembungnya profil curvature (Error! Reference source not found.1). Kandungan pasir semakin tinggi pada profil lereng yang cekung. Percepatan aliran air akan menurun pada profil curvature yang cekung, sehingga daya angkutnya akan menurun dan akhirnya banyak pasir yang diendapkan.

Hal yang sebaliknya terjadi dengan fraksi liat. Arah hubungan negatif antara kandungan liat dan profil curvature menunjukkan bahwa kandungan liat relatif menurun pada profil lereng yang cekung (Error! Reference source not found.2). Hal ini diduga karena perlambatan aliran air belum mampu mengendapkan fraksi liat, sehingga fraksi liat masih terbawa oleh aliran air permukaan dan baru terendapkan di bagian lereng yang datar dan lereng bagian bawah. 


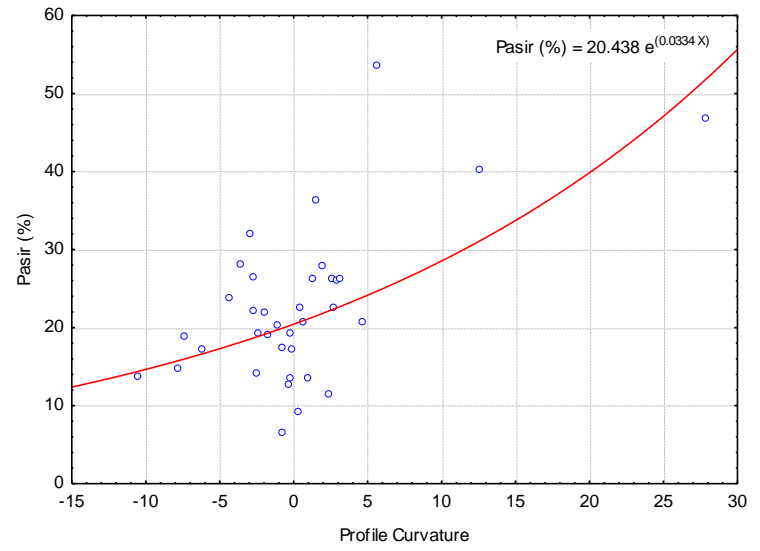

a

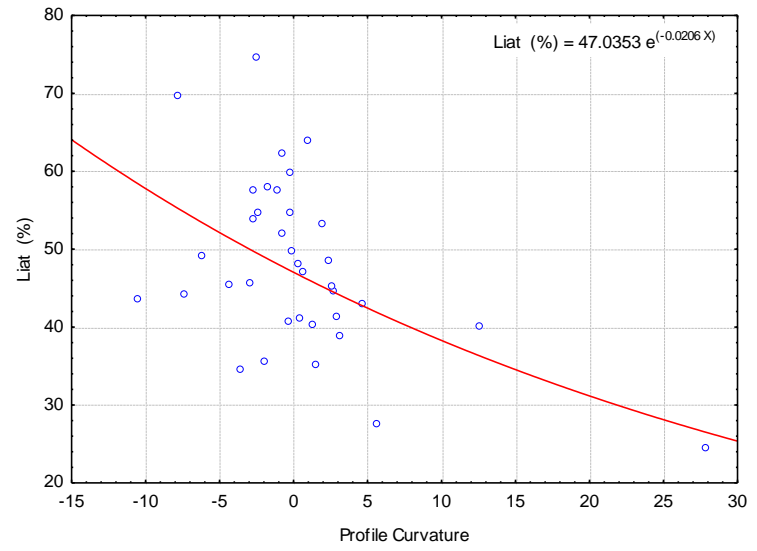

$\mathrm{b}$

Gambar 2 Hubungan antara profile curvature dengan kandungan pasir (a); hubungan antara profile curvature dengan kandungan liat (b).

\subsection{Plan Curvature}

Plan curvature merupakan laju perubahan kemiringan tegak lurus terhadap arah kemiringan lereng atau searah dengan arah kontur. Variabel ini berperan dalam penyebaran dan pemusatan arah pergerakan aliran air. Aliran air akan memusat pada plan curvature cekung dan sebaliknya, aliran air akan menyebar pada plan curvature yang cembung. Berbeda dengan profile curvature, plan curvature bernilai negatif untuk bentuk yang cekung (cconvergent) dan nilai positif untuk yang cembung (divergent).

Berdasarkan gambaran interpretasi plan curvature (Gambar 3) sebagian wilayah menunjukkan nilai sekitar nol. Oleh karena itu, arah pemusatan aliran di lokasi penelitian sebagian besar tegak lurus dengan lereng.
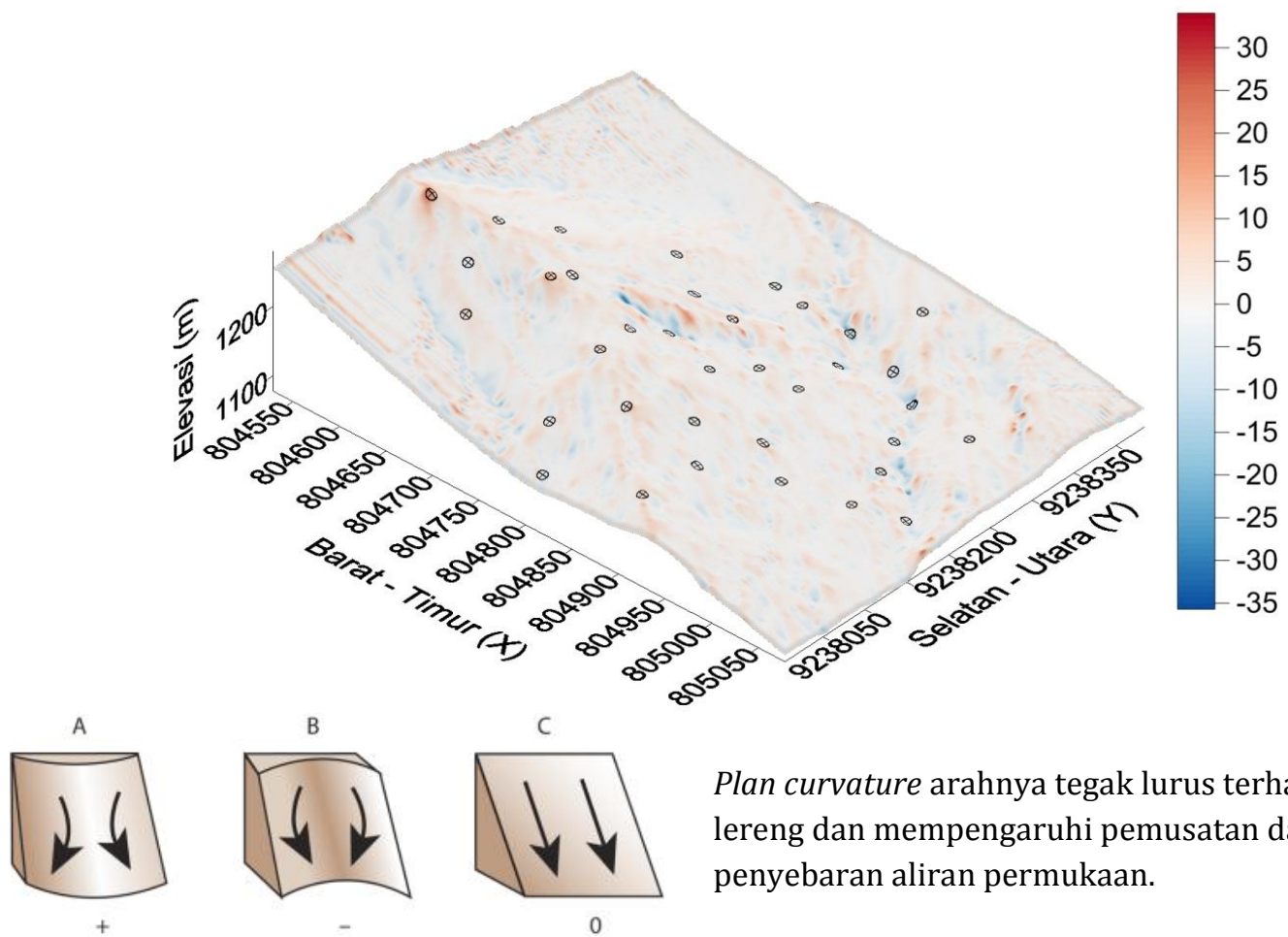

Plan curvature arahnya tegak lurus terhadap arah lereng dan mempengaruhi pemusatan dan penyebaran aliran permukaan. 
Gambar 3 Hasil interpretasi plan curvature di lokasi penelitian

Tinggi rendahnya kecepatan aliran air tergantung pada kombinasinya dengan profil curvature. Percepatan pergerakan aliran air di permukaan akan semakin meningkat pada profile curvature yang cembung dan sebaliknya, terjadi perlambatan pada profile curvature cekung. Pada kasus ini, diduga plan curvature banyak yang berasosiasi dengan profile curvature yang cekung, sehingga pemusatan pergerakan aliran air tidak terlalu cepat dan akhirnya banyak fraksi pasir yang terendapkan di daerah plan curvature yang cekung. Aliran air akan memusat pada plan curvature yang cekung.

Plan curvature berpengaruh terhadap distribusi partikel tanah terutama pada ukuran partikel pasir dan debu (Tabel 2). Pola hubungan antara plan curvature dan distribusi partikel pasir dan debu dapat dilihat pada Gambar 4. Distribusi partikel

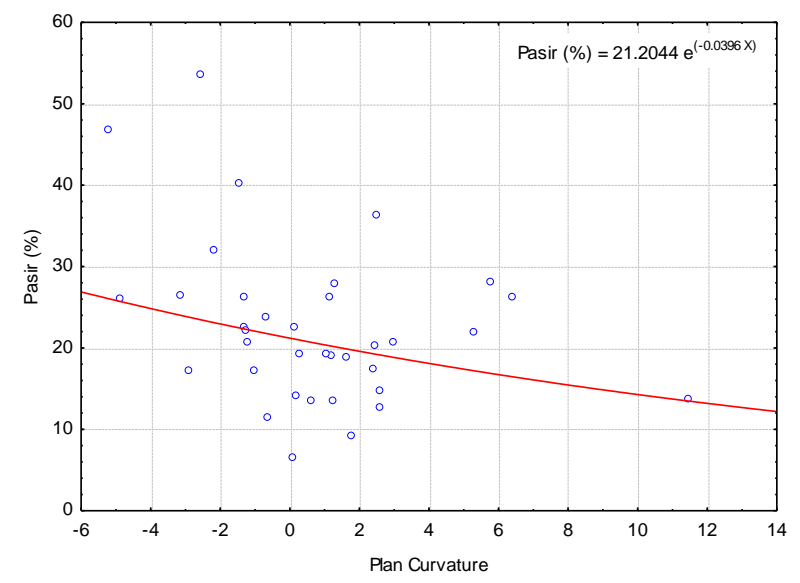

a tanah erat kaitannya dengan proses hidrologi dan erosi. Meskipun daya angkut aliran air tidak terlalu besar, akan tetapi masih mampu membawa partikel yang ukurannya lebih kecil seperti debu.

Kandungan pasir semakin meningkat pada plan curvature yang cekung. Kandungan debu relatif lebih rendah pada plan curvature yang cekung dan sebaliknya, kandungan debu semakin meningkat pada lereng yang semakin cembung. Hubungan yang searah antara debu dan plan curvature mengindikasikan bahwa kandungan debu relatif lebih tinggi pada plan curvature yang cembung. Aliran air akan menyebar pada plan curvature yang cembung sehingga energi kinetik aliran airpun akan berkurang (menyebar). Dengan demikian, tingkat erosi akan sedikit menurun dan mungkin saja terjadi deposisi sementara dari fraksi debu.

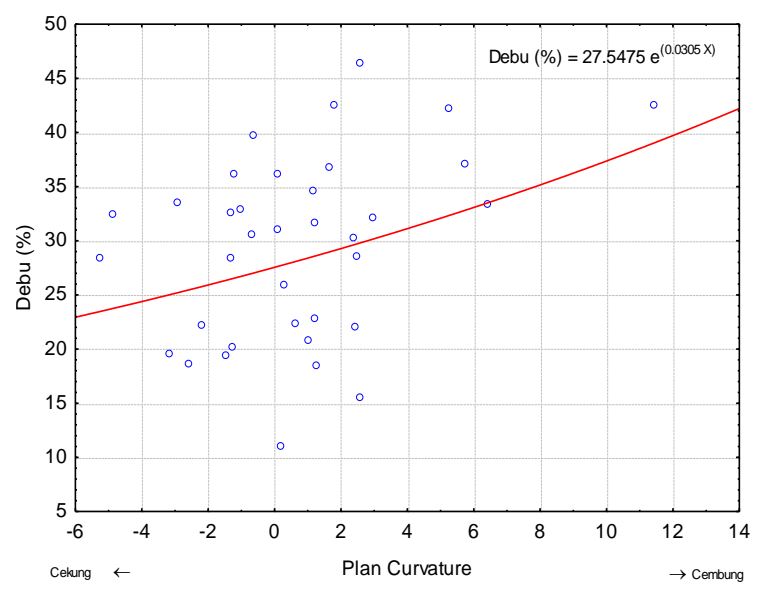

$\mathrm{b}$

Gambar 4 Hubungan antara plan curvature dengan kandungan pasir (a); hubungan antara profile curvature dengan kandungan debu (b).

\subsection{Topographic Position Index}

Topographic Position Index (TPI) adalah perbedaan ketinggian antara suatu titik dengan rata-rata dari ketinggian daerah sekitarnya. Nilai TPI yang positif menandakan bahwa lokasi tersebut lebih tinggi dibanding daerah sekitarnya, sementara nilai negatif menandakan lokasi tersebut lebih rendah dibandingkan dengan daerah sekitarnya, biasanya berupa lembah. TPI ini merupakan penyederhanaan dari Indeks Posisisi Landskap (Landscape Position Index) yang selanjutnya dikembangkan secara detail oleh Weiss (2001).

Berdasarkan hasil interpretasi TPI (Gambar 5), bentuk lahan di lokasi penelitian 
bergelombang. Punggungan (igir) terlihat terbentuk melintak searah dengan lereng (walaupun tidak percis tegak lurus), demikian juga dengan pelembahan.

Banyak variabel sifat-sifat fisika tanah yang berhubungan erat dengan variabel TPI. Kandungan pasir, bobot isi tanah, kandungan C-organik dan porositas semuanya berhubungan dengan nilai TPI (Tabel 2). Posisi topografi yang lebih tinggi dibanding dengan daerah sekitarnya cenderung mempunyai kandungan pasir, kandungan Corganik dan porositas yang rendah dibanding dengan daerah sekitarnya yang lebih rendah (lembah). Seiring dengan proses erosi, kandungan pasir dan C-organik banyak yang diendapkan di daerah yang lebih rendah (Arsyad, 2010). Sebaliknya, bobot isi tanah cenderung lebih tinggi dengan semakin semakin meningkatnya nilai TPI.

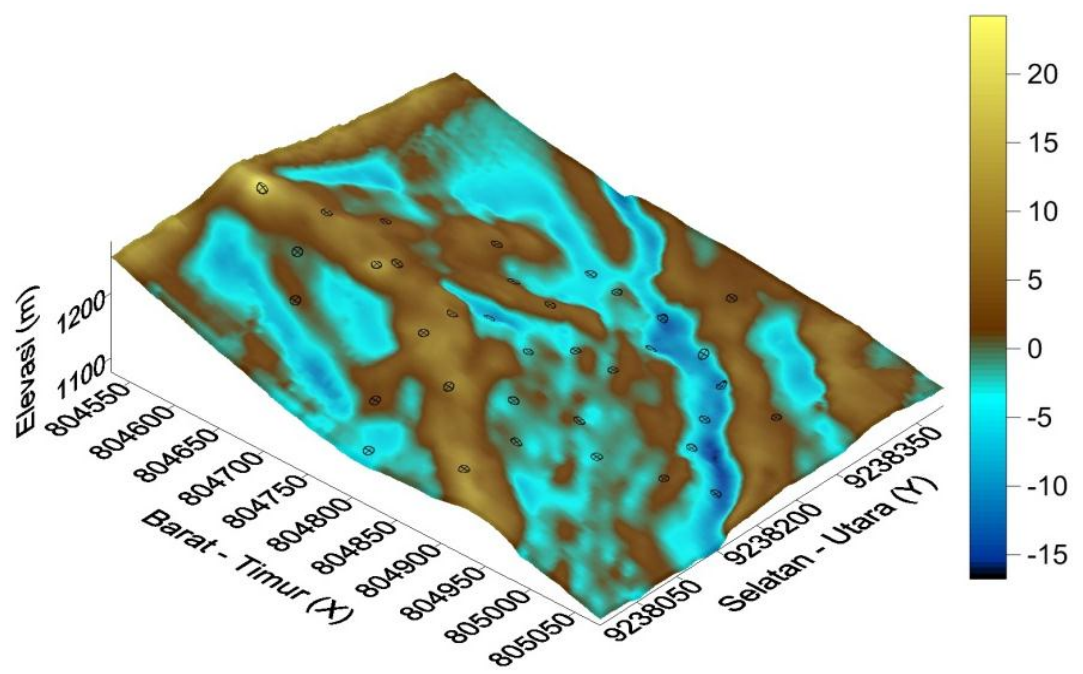

Gambar 5 Hasil interpretasi indeks posisi topografi (TPI) di lokasi penelitian

\subsection{Topographic Wetness Index}

Topographic Wetness Index (TWI) menggambarkan kontrol topografi terhadap kelembaban tanah (Wilson dan Gallant, 2000). Penilaian TWI secara kuantitatif dapat menjadi dasar penilian efek topografi lokal terhadap limpasan air hujan (Qin et al., 2011).

Nilai TWI merupakan salah satu indikator untuk daerah yang rawan banjir (tergenang) dengan nilai TWI tinggi, ataupun daerah yang sering mengalami kekeringan yang berasosiasi dengan nilai TWI rendah.

Berdasarkan hasil interpretasi TWI di lokasi penelitian (Gambar 6), nilai indeks kebasahan berada di atas 1. Hal ini menunjukkan bahwa daerah penelitian cukup lembab dan potensi kekeringan sangat kecil. Nilai TWI semakin tinggi di wilayah pelembahan yang menjadi daerah konsentrasi air limpasan.

Banyak variabel sifat-sifat fisika tanah yang berhubungan erat dengan variabel TWI. Kandungan debu, kandungan C-organik, bobot isi tanah dan porositas berhubungan dengan nilai TWI (Tabel 2). Kandungan debu semakin rendah dengan semakin meningkatnya nilai TWI. Tanah dengan kandungan pasir halus atau debu yang tinggi sangat rentan terhadap erosi interrill dan rill sedangkan kandungan tanah liat yang tinggi umumnya tingkat kerentanan tanah terhadap erosi interrill akan berkurang (Arsyad, 2010). Tempat yang mengalami erosi interrill dan rill biasanya berasosiasi dengan nilai TWI yang tinggi sehingga kandungan debu pada tanah yang mudah tererosi akan semakin berkurang karena terbawa aliran air. 
Kandungan C-organik semakin meningkat dengan semakin meningkatnya nilai TWI. Korelasi antara kandungan C-organik dengan TWI relatif konsisten dengan hasil penelitian lain.

Pada kondisi lingkungan yang berbeda, Corganik berkorelasi dengan variabel topografi dan hal ini terutama disebabkan oleh dinamika pergerakan aliran air. Daerah yang lebih lebih rendah serta gradien kemiringan rendah atau cekungan berhubungan dengan kandungan C-organik yang tinggi karena penurunan kecepatan air yang mengalir yang datang dari bukit, sehingga memungkinkan sedimentasi dan akumulasi dari C organik (Gregorich dkk., 1998). Proses penting lainnya yang menyebabkan kandungan C-organik lebih besar pada posisi lereng bawah diduga karena potensi mineralisasi yang lebih rendah (Janzen, 2006).

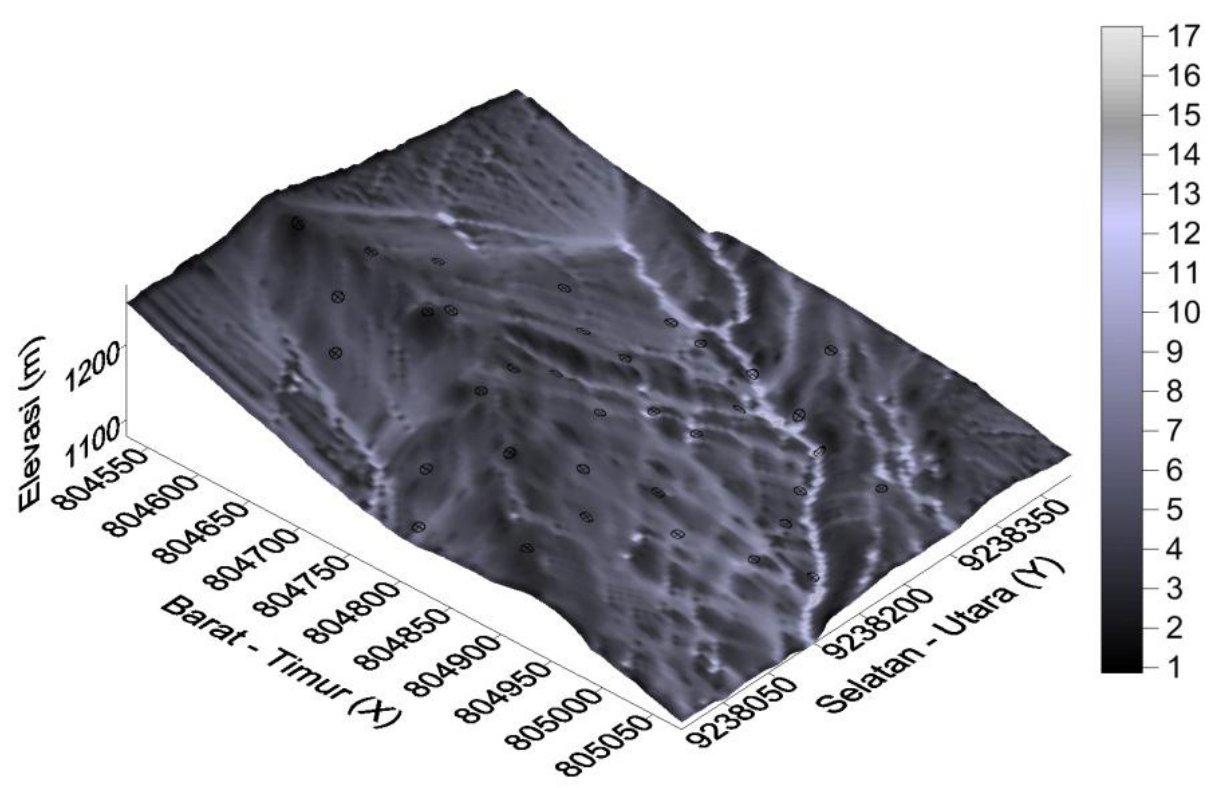

Gambar 6 Hasil interpretasi nilai indeks kebasahan (TWI) di area penelitian

Bobot isi tanah semakin menurun dengan meningkatnya nilai TWI ( $\left.\mathrm{r}=-0,39^{*}\right)$, sedangkan porositas sejalan dengan peningkatan nilai TWI $\left(\mathrm{r}=0,39^{*}\right)$. Hubungan keeratan antara kandungan $\mathrm{C}$-organik dengan bobot isi nyata $\left(\mathrm{r}=-0,36^{*}\right)$ demikian juga dengan porositas $\left(r=0.36^{*}\right)$. Peningkatan dan penurunan bobot isi dan porositas diduga ada hubungannya dengan peningkatan dan penurunan kandungan C-organik.

\section{KESIMPULAN}

Semua variabel topografi berhubungan dengan satu atau lebih sifat-sifat tanah, kecuali aspect dan slope yang tidak menunjukkan adanya hubungan dengan parameter sifat-sifat fisika tanah. Variable topografi mempengaruhi arah aliran air yang dapat berpengaruh kepada proses perkembangan tanah. Variabel topografi yang paling sering berhubungan dengan sifat-sifat tanah adalah TPI dan TWI.

\section{DAFTAR PUSTAKA}

Arsyad, S. 2010. Konservasi Tanah dan Air. IPB Press. Bogor.

Beven, K.J. and M.J Kirkby. 1979. A Physically Based, Variable Contributing Area Model of Basin Hydrology. Hydrological Sciences Bulletin 24: 4369. 
Evans, I.S. 1980. An integrated system of terrain analysis and slope mapping. A. Geomorphol., Suppl. Bd. 36:274-295.

Gregorich, E.G., K.J. Geer, D.W. Anderson, and B.C. Liang. 1998. Carbon Distribution and Losses: Erosion and Deposition Effects. Soil Tillage Res. 47:291-302.

Janzen, H.H. 2006. The Soil Carbon Dilemma: Shall We Hoard It or Use It? Soil Biol. Biochem. 38:419-424.

Jenny H., 1941. Factors of Soil Formation. McGraw-Hill, New York.

McKenzie, N.J., Ryan, P.J., 1999. Spatial Prediction of Soil Properties Using Environmental Correlation. Geoderma 89, 67-94.

Mitasova, H., and J. Hofierka. 1993. Interpolation by Regularized Spline with Tension: II. Application to Terrain Modeling and Surface Geometry Analysis. Math. Geol. 25:657-669.

Moore, I.D., Grayson, R. B. and Ladson, A. R. 1991. Digital Terrain Modelling: A Review of Hydrological, Geomorphological and Biological Applications, Hydrolog. Proc. 5, 3-30.

Pachepsky, Y.A, D. J. Timlin, and W. J. Rawls. 2001. Soil Water Retention as Related to Topographic Variables. Soil Sci. Soc. Am. J. 65:1787-1795

Qin, C. Z., A. Zhu, T. Pei, B.L. Li, T. Scholten, T., Behrens, C.H. Zhou. 2011. An approach to computing topographic wetness index based on maximum downslope gradient. Precision Agriculture, 12(1): 32-43.

Ruhe, R.V. 1956. Geomorphic Surfaces and The Nature of Soils. Soil Sci. 82:441-455.

Simonson, R. W. 1968. Concept of soil. Adv. Agron., 20, 1-47.
Wilding, L.P. and Drees, L.R. 1983. Spatial Variability and Pedology. in: Wilding, L.P.; Smeck, N.E. \& Hall, G.F., eds. Pedogenesis and Soil Taxonomy. I. Concepts and Interactions. Amsterdam, Elsevier Science, 1983. p.83-116.

Wilson, J.P. and Gallant, J.C. 2000. Secondary Topographic Attributes, in: Terrain Analysis: Principals and Applications, Wilson, J. P. \& Gallant, J. C. (eds.), Wiley, New York, USA

Zhu, A.X., B. Hudson, J. Burt, K. Lubich, and D. Simonson. 2001. Soil Mapping Using GIS, Expert Knowledge, and Fuzzy Logic. Soil Sci. Soc. Am. J. 65:14631472. 